\title{
Palaeoclimatic control of Upper Pliocene Discoaster assemblages in the North Atlantic
}

\author{
ALEX. CHEPSTOW-LUSTY', JAN BACKMAN ${ }^{2}$ and NICHOLAS J. SHACKLETON' \\ 'Godwin Laboratory, Subdepartment of Quaternary Research, \\ University of Cambridge, Cambridge CB2 3RS \\ ${ }^{2}$ Department of Geology, University of Stockholm, S-106 91 Stockholm
}

\begin{abstract}
Abundance variations of six Pliocene species of the nannofossil genus Discoaster were analyzed over the time interval 1.89-2.95 Ma at five sites in the North Atlantic; DSDP 552 $\left(56^{\circ} \mathrm{N}\right)$, DSDP $607\left(41^{\circ} \mathrm{N}\right)$, ODP $659\left(18^{\circ} \mathrm{N}\right)$, ODP $658\left(20^{\circ} \mathrm{N}\right)$ and ODP $662\left(1^{\circ} \mathrm{S}\right)$. Individual species are compared between the five sites as a percentage of the total Discoaster assemblage, using age models based mainly on Discoaster datums ( 3 control points used at each site). The sampling interval is approximately 3 kyrs.

Discoaster brouweri, the only species covering the complete time interval became a less significant component of the assemblages with increasing latitude during the interval prior to 2.3 Ma. Discoaster triradiatus shows a distinct abundance acme at all sites between 1.89-2.7 Ma. Discoaster surculus increased in relative abundance with higher latitudes and upwelling conditions (ODP Site 658).

Discoaster pentaradiatus is an important component of the assemblages at all sites, but displays an inverse abundance relationship with $D$. surculus as a function of increasing latitude and upwelling conditions. Discoaster tamalis and Discoaster asymmetricus are reduced at low latitudes and in upwelling conditions and increase relative to $D$. brouweri at higher latitudes, where there is strong evidence for taxonomic affinity.
\end{abstract}

\section{INTRODUCTION}

Discoasters are considered to be the calcareous discs of an extinct group of enigmatic phytoplankton which were presumably related to the coccolithophorids. The last two surviving representatives of the genus Discoaster disappeared globally at 1.89 Ma (Takayama, 1970; Backman \& Shackleton, 1983; Backman et al., 1986 and Backman \& Pestiaux, 1987).

In this study we are investigating the individual species as a percentage of the total Discoaster assemblage at five contrasting sites in the North Atlantic in the one million years prior to their final extinction. The data for the absolute abundances of the individual Discoaster species and the total Discoaster assemblage is shown by Chepstow-Lusty et al., (1989).

Many studies have concluded that high Discoaster abundance is related to warm water masses since they are especially common in low-latitude sediments (Haq \& Lohmann, 1976; Bukry, 1978). Chepstow-Lusty et al., (1989) demonstrated for the first time that the high variation, particularly in the Tropics, cannot only be related to temperature changes, but must also involve productivity controls.

The sampling interval used is approximately 3 kyrs. The smear slide preparation and counting method used here is described in Backman \& Shackleton (1983). The same paper gives a succinct taxonomy of the six species of discoasters referred to in the present paper (Plate 1).

\section{SITES SELECTED}

The five sites selected (Fig. 1, Table 1) contrast with each other either in terms of latitude or upwelling versus non-upwelling situations. Sampling was at $10 \mathrm{~cm}$ intervals except for Sites 607 and 658 , which were at $15 \mathrm{~cm}$ and $30 \mathrm{~cm}$ intervals respectively.

Site 662 is located close to the Equator on the upper, eastern flank of the Mid-Atlantic Ridge. Site 659 was chosen as the non-upwelling, open ocean reference site, and is located on the top of the Cape Verde Plateau. Site 658 is a contrasting, high productivity, upwelling site in close proximity to Site 659 , located $160 \mathrm{~km}$ west of Cape Blanc and lying beneath a major, highly productive cell of oceanic upwelling.

Site 607 is located along the northernmost part of the present-day Subtropical Gyre, but in the Late Pliocene it was subjected to major circulation changes and lower temperatures (Ruddiman, Sarnthein et al., 1988) Site 552 is the northernmost site selected and is located on the southwest margin of the Rockall Plateau. For further information concerning these sites 


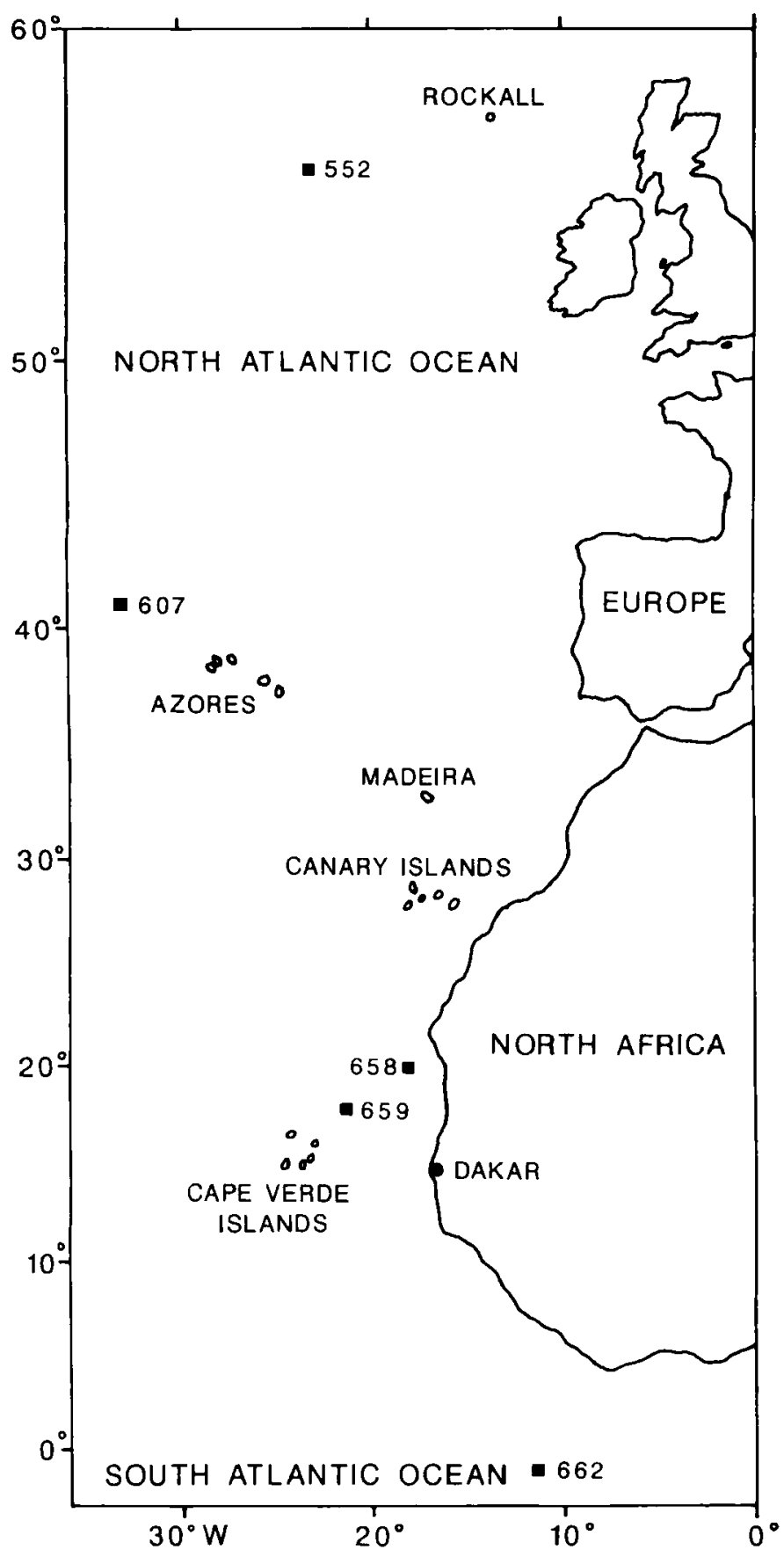

Fig 1. Location of sites studied in the North Atlantic. refer to Roberts, Schnitker et al. (1984); Ruddiman, Kidd, Thomas et al. (1987) and Ruddiman, Sarnthein et al. (1988).

\section{AGE MODELS AND SEDIMENTATION RATES}

To compare the five sites age models had to be constructed. This process is discussed in great detail in Chepstow-Lusty et al. (1989).

At Sites 659 and 662 magnetostratigraphic data was not available, and at Site 658 it was found to be inaccurate, so that all age models for these sites are based on biostratigraphic datums. Sites 607 and 552 had reliable magnetic stratigraphies. The age models constructed are based on only three stratigraphic datums at each site. Biostratigraphic datums were selected preferentially if possible, especially Discoaster datums (Table 2). The logic behind this procedure was to obtain age models that were consistent between the five sites (Table 3). The datums for Globoquadrina altispira at Sites 658 and 662, an extremely useful planktonic foraminiferal datum, come from Weaver \& Raymo (1989). Sedimentation rates are very high at the upwelling site, Site 658 , and lowest at the highest latitude site, Site 552.

\section{COMPARISON OF SPECIES COMPOSITION WITHIN THE DISCOASTER ASSEMBLAGE BETWEEN SITES}

The absolute abundances of total discoasters and $D$. broun'eri shown by Chepstow-Lusty et al. (1989) display marked differences of abundance between high and low latitudes, and between upwelling versus non-upwelling situations. Trends in the other species show different patterns, but there is always a sudden reduction in abundance of all species of Discoaster studied between $41^{\circ}$ and $56^{\circ} \mathrm{N}$. Discoasters as a group do not favour cool water masses, but by representing individual Discoaster species as a percentage of the total Discoaster assemblage, some of the trends in the absolute abundance data may be further refined to yield additional information. The absolute abundance differences in discoasters between, e.g. Site $552\left(56^{\circ} \mathrm{N}\right)$ and Site $662\left(1^{\circ} \mathrm{S}\right)$, present major scaling problems, and therefore this technique also provides an alternative method of making comparisons.

\section{TABLE 1}

North Atlantic sites selected, their geographic positions and water depth.

$\begin{array}{llll}\text { Hole } & \text { Location } & \text { Depth (m) } & \text { Reference } \\ & & & \\ 662 \mathrm{~A} & 1^{\circ} \mathrm{S} 11^{\circ} \mathrm{W} & 3,824 & \text { Ruddiman, Sarnthein, et al., } 1988 \\ 659 \mathrm{~A} & 18^{\circ} \mathrm{N} 21^{\circ} \mathrm{W} & 3,067 & " \\ 658 \mathrm{~A} & 2^{\circ} \mathrm{N} 18^{\circ} \mathrm{W} & 2,263 & " \\ 607 & 41^{\circ} \mathrm{N} 33^{\circ} \mathrm{W} & 3,427 & \text { Ruddiman, Kidd, Thomas, etal., } 1987 \\ 552 \mathrm{~A} & 56^{\circ} \mathrm{N} 23^{\circ} \mathrm{W} & 2,304 & \text { Roberts, Schnitker, et al., 1984 }\end{array}$


TABLE 2

Summary of Discoaster events between 3.00 and $1.89 \mathrm{Ma}$, based on previous work (e.g. Backman \& Shackleton, 1983; Backman, etal., 1986). *Estimate for extinction from this study.

$\begin{array}{lll}\text { Species } & \text { Age (Ma) } & \text { Event } \\ \text { D. brouweri } & 1.89 & \text { Extinction } \\ \text { D. triradiatus } & 1.89 & \text { Extinction } \\ \text { D. triradiatus } & 2.07 & \text { Peak Abundance began } \\ \text { D. pentaradiatus } & 2.43-2.33 & \text { Extinction } \\ \text { D. surculus } & 2.46-2.42 & \text { Extinction } \\ \text { D. surculus } & 2.39 & \text { Extinction } \\ \text { D. asymmetricus } & 2.65 & \text { Abundance decline } \\ \text { D. tamalis } & 2.65 & \text { Extinction } \\ \text { D. variabilis } & 2.93-2.87 & \text { Extinction }\end{array}$

Species are shown only for the time interval through which they range. Reworked species in low abundance intervals of $D$. brouweri can result in high percentage representation, which distorts the apparent species distribution in time, and may potentially cause confusion. However this type of representation may prove a useful way of investigating the cyclicity of reworking. Discontinuities in the plots indicate loss of material at core breaks.

\section{Discoaster brouweri and Discoaster triradiatus}

Both these species become extinct at $1.89 \mathrm{Ma}$. D. brouweri is the only species occurring throughout the complete time-interval studied (3.00-1.89 Ma). Apart from the brief acme of $D$. triradiatus, $D$. brouweri is the sole surviving Discoaster species between approximately 2.35 and $1.89 \mathrm{Ma}$ (Fig. 2). An interesting feature of the other Discoaster species is that before $2.35 \mathrm{Ma}$ they form a greater component of the total Discoaster assemblage with increasing latitude. It appears that shortly after the initiation of major glaciation in the North Atlantic at $2.4 \mathrm{Ma}$ (Shackleton et al., 1984), essentially only D. brouweri continues, as the last surviving Discoaster species.

D. triradiatus is insignificant in abundance until $2.07 \mathrm{Ma}$ (Backman \& Shackleton, 1983), when it increases to the proportion of $20 \%$ relative to $D$. brouweri (Fig. 3 ). This acme is observed at all sites including Site 552, where the time resolution and abundances are however very low. These two species are believed to be strongly related taxonomically. Their final extinction of may be slightly disguised by reworking of them in very low numbers, but producing anomalously high percentages. Absolute abundances should therefore also be referred to when defining this event.

\section{Discoaster pentaradiatus and Discoaster surculus}

These two species have been compared in different cores and ocean basins by Backman \& Shackleton (1983), Backman et al. (1986) and Backman \& Pestiaux (1987). Their extinctions are estimated to occur between 2.45 and 2.35 Ma. The general consensus is that $D$. surculus disappeared slightly earlier than $D$. pentaradiatus, which is also the case at the five sites studied here. Anomalous percentages beyond the extinction events specified here are due to reworking during periods of low abundances of $D$. brouweri.

In the time-interval 3.0-2.3 Ma, D. pentaradiatus (Fig. 4) constantly forms a high proportion of the Discoaster assemblage from low to high latitudes and from upwelling to non-upwelling situations. An apparent trend, however, is an increase in the proportion of $D$. pentaradiatus within the complete Discoaster assemblage between 2.50 and $2.38 \mathrm{Ma}$ as a function of increasing latitude and upwelling conditions.

At Sites 659, 658,607 and 552 a distinct and synchronous extinction of $D$. pentaradiatus was recorded at approximately $2.38 \mathrm{Ma}$. However, at Site 662 the extinction event was less easy to define owing to reworking, but was estimated to occur between 2.41 and $2.34 \mathrm{Ma}$.

$D$. surculus was found to end with a final sharp peak at the end of its range in Sites 658,659 and 662 , which is assumed to be synchronous (Fig.5). At Site 659, where the Plio-Pleistocene sedimentation rate appears to be constant (Ruddiman, Sarnthein et al., 1988), the Last Appearance Datum (LAD) of D. surculus was found to be the only biostratigraphic datum that did not fit the apparently linear sedimentation rate. The age estimate of $D$. surculus, when adjusted to fit the linear sedimentation rate gave a value of $2.39 \mathrm{Ma}$ for the final peak (Chepsiow-Lusty et al., 1989), which is within the range of estimales obtained from Core V32-127 (Backman \& Shackleton. 198.3). The age of 2.39 Ma for this final peak of $D$. surculus hals therefore been applied to all the age models for intemal consistency (Table 3).

The final peak of $D$. surculus is clearly shown in the absolute abundances at Sites 658,659 and 662, but not at Sites 607 or 552. However. by representing D. surculus as a percentage of the complete Discoaster assemblage the final peak is also well defined at the two latter sites. Sites 607 and 658 once again demonstrate the problem of 0905 reworking in a low abundance interval of $D$. brouweri, after approximately $2.39 \mathrm{Ma}$.

$D$. surculus shows a clear trend of increasing abundance within the Discoaster assemblage as a function of increasing latitude and upwelling conditions. Bukry (1978) noted that $D$. surculus favoured the cooler end of the spectrum occupied by the warm water genus Discoaster, and this is clearly confirmed here.

In all five sites $D$. pentaradiatus and $D$. surculus were frequently observed to display an inverse abundance relationship (Backman \& Shackleton, 1983). These two species are believed to have different ranges of ecological tolerance. $D$. surculus is therfore finally represented here as a plot of its percentage as a proportion of the sum of $D$. surculus and $D$. pentaradiatus (Fig. 6). This emphasizes that $D$. surculus increases with latitude and upwelling conditions, and further defines the final peak at $2.39 \mathrm{Ma}$. 


\section{TABLE 3}

Summary of control points used in age-models.

(mbst $=$ metres below sea floor)

\begin{tabular}{|c|c|c|c|c|}
\hline Datum & Age (Ma) & Depth (mbsf) & Event & Sedimentation Rate \\
\hline \multicolumn{5}{|l|}{ HOLE 659A } \\
\hline D. brouweri & 1.89 & 54.8 & Extinction & $3.2 \mathrm{~cm} / \mathrm{kyrs}$ \\
\hline D. triradiatus & 2.07 & 60.6 & Peak Abundance began & $3.2 \mathrm{~cm} / \mathrm{kyrs}$ \\
\hline D. tamalis & 2.65 & 79.4 & Extinction & \\
\hline \multicolumn{5}{|l|}{ HOLE 658A } \\
\hline D. brouweri & 1.89 & 126.4 & Extinction & $7.9 \mathrm{~cm} / \mathrm{kyrs}$ \\
\hline D. surculus & 2.39 & 166.0 & Extinction & $9.6 \mathrm{~cm} / \mathrm{kyrs}$ \\
\hline G. altispira & 2.95 & 220.0 & Extinction & \\
\hline \multicolumn{5}{|l|}{ HOLE 662A } \\
\hline D. brouweri & 1.89 & 123.2 & Extinction & $5.6 \mathrm{~cm} / \mathrm{kyrs}$ \\
\hline D. surculus & 2.39 & 151.4 & Extinction & $3.1 \mathrm{~cm} / \mathrm{kyrs}$ \\
\hline G. altispira & 2.95 & 168.5 & Extinction & \\
\hline \multicolumn{5}{|l|}{ HOLE 607} \\
\hline D. brouweri & 1.89 & 82.86 & Extinction & $4.8 \mathrm{~cm} / \mathrm{kyrs}$ \\
\hline D. surculus & 2.39 & 106.78 & Extinction & $4.0 \mathrm{~cm} / \mathrm{kyrs}$ \\
\hline Kaena & 2.99 & 130.73 & base & \\
\hline HOLE 552A & & & & \\
\hline D. brouweri & 1.89 & 35.2 & Extinction & $1.4 \mathrm{~cm} / \mathrm{kyrs}$ \\
\hline D. surculus & 2.39 & 42.5 & Extinction & $1.0 \mathrm{~cm} / \mathrm{kyrs}$ \\
\hline Kaena & 2.99 & 48.6 & base & \\
\hline
\end{tabular}

\section{Discoaster asymmetricus and Discoaster tamalis}

The absolute abundance plots (Chepstow-Lusty et al., 1989) demonstrated that these two species co-vary almost identically. Backman \& Shackleton (1983), Backman et al. (1986) and Backman \& Pestiaux (1987) have also recorded this phenomenon, and it is widely agreed that these species are taxonomically related. This co-variation can also be demonstrated by comparing the percentage abundance plots of these two species (Fig. 7 and 8). Furthermore, these two species also co-vary with $D$. brouweri to which they appear to be related.

The extinction event for D. tamalis, and abundance decline of D. asymmetricus, at $2.65 \mathrm{Ma}$ is slightly disguised by rework-

Fig. 1 Discoaster brouweri Tan Sin Hok. Fig. 2. Discoaster triradiatus Tan Sin Hok. Fig. 3. Discoaster pentaradiatus Tan Sin Hok. Fig. 4. Discoaster surculus Martini \& Bramlette. Fig. 5. Discoaster asymmetricus Gartner. Fig. 6. Discoaster tamalis Kamptner. 


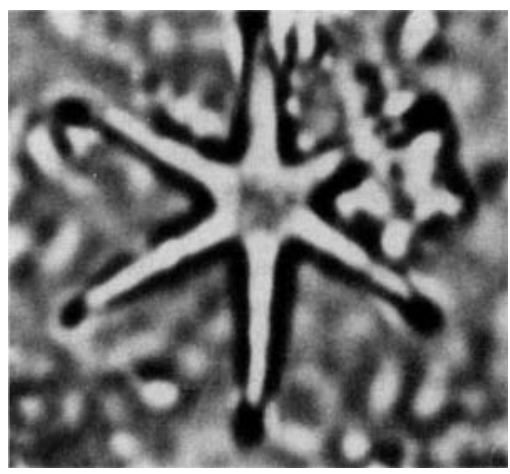

1

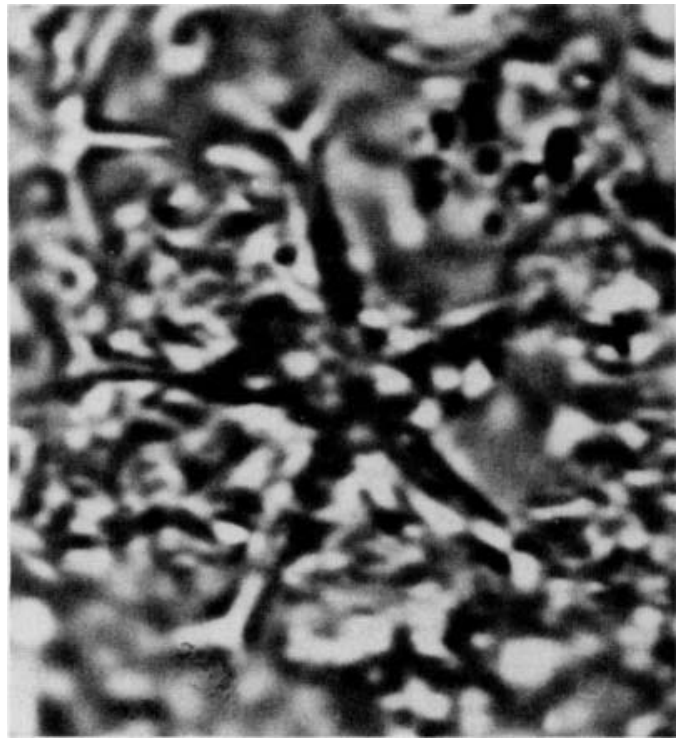

3

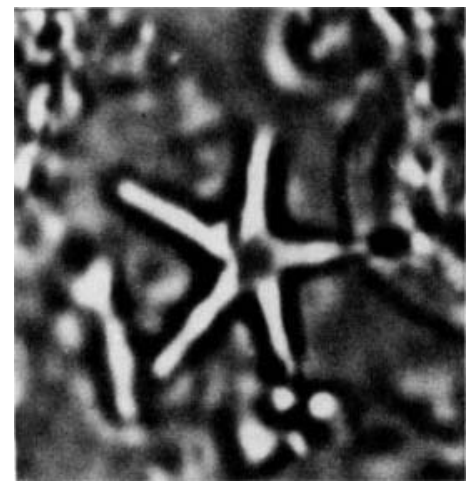

5

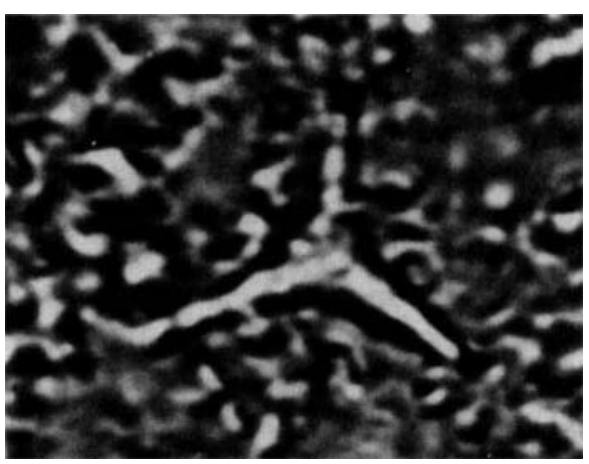

2

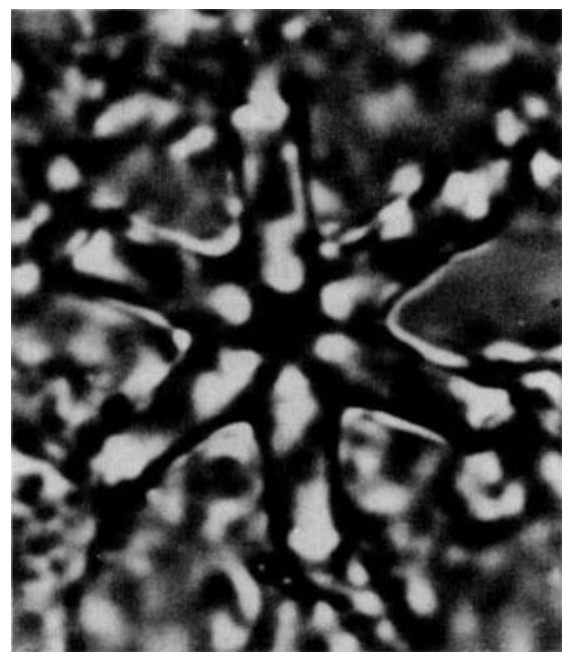

4

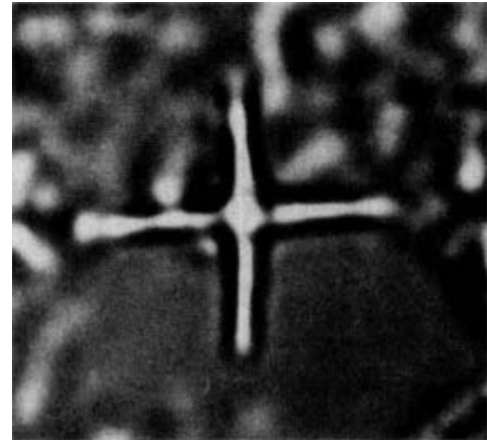

6

10u 
ing, or presence in low numbers, except at Sites 659 and 662. The trend to notice is the percentage increase in abundance within the complete Discoaster assemblage for both these species with increasing latitude, but not with upwelling conditions. This can be further emphasized by representing $D$. tamalis as a percentage of the sum of $D$. tamalis, D. asymmetricus and $D$. brouweri, which may in fact be one biological species (Fig. 9). Similarly, the same trend can be shown by representing the sum of $D$. tamalis and $D$. asymmetricus as a percentage of the sum of these two species and D. brouweri (Fig. 10). Upwelling appears to suppresss the production of these two species at Site 658. Site 662, which is located within the Equatorial Divergence, should be affected by upwelling to some degree, causing a similar suppression.

\section{CONCLUSIONS}

Prior to $2.35 \mathrm{Ma}$, Discoaster brouweri decreases as a percentage of the complete Discoaster assemblage with increasing latitude. The related species Discoaster tamalis and Discoaster asymmetricus reached a critical threshold at $2.65 \mathrm{Ma}$ following which these forms stopped being produced or were produced very rarely. Prior to $2.65 \mathrm{Ma}$ the production of these two types of discs was favoured by cooler water masses unassociated with upwelling.

Until approximately $2.3 \mathrm{Ma}$, Discoaster pentaradiatus forms a major stable component of the total Discoaster assemblage across both latitude and upwelling versus non-upwelling conditions. Prior to approximately $2.39 \mathrm{Ma}$, Discoaster surculus increased as a component of the total Discoaster assemblage with both higher latitudes and upwelling conditions. Major changes in the Discoaster assemblage, leaving $D$. brouweri as the sole survivor from shortly afterwards, correlate with the strong changes in Northern Hemisphere climate at $2.4 \mathrm{Ma}$.

Representing Discoaster species as a percentage of the total Discoaster assemblage reveals additional ecological information not clearly shown by the absolute abundances. Similar research is being carried out on cores with high time resolution from the Pacific and Indian Oceans at Sites 677, 716 and 709. It will be interesting to see if the latitudinal and upwelling versus non-upwelling trends revealed in the Atlantic are applicable globally.

\section{ACKNOWLEDGEMENTS}

We thank the Ocean Drilling Program and the shipboard scientists of ODP Leg 108 and DSDP Legs 81 and 94, who made this study possible. Alex. Chepstow-Lusty was supported by a Natural Environment Research Council Research Studentship, BP plc. and the Cherry Foundation.

\section{REFERENCES}

Backman, J., Pestiaux, P., Zimmerman, H., and Hermelin, O., 1986, Pliocene palaeoclimatic and palaeoceanographic development in the Pliocene North Atlantic: Discoaster accumulation and coarse fraction data. Geological Society Special Publication, No. 21, 231-242.

Backman, J., and Shackleton, N. J., 1983, Quantitative biochronology of Pliocene and early Pleistocene calcareous nannofossils from the Atlantic, Indian and Pacific oceans. Mar. Micropalontol.,8, 141-170.

Backman, J., and Pestiaux, P., 1987, Pliocene Discoaster abundance variations from DSDP Site 606: biochronology and paleoenvironmental implications. Init. Repts. DSDP, 94, 903-910.

Bukry, D., 1978, Biostratigraphy of Cenozoic marine sediment by calcareous nannofossils. Micropaleontol., 24, 44-60.

Chepstow-Lusty, A., Backman, J., and Shackleton, N. J., 1989, Comparison of UpperPliocene Discoaster abundance variations from North Atlantic Sites 552, 607, 658, 659, and 662: further evidence for marine plankton responding to orbital forcing. Proc. ODP, Sci. Results, 108, 121-141.

Haq, B. U., Lohmann, G. P., 1976, Early Cenozoic calcareous nannoplankton biogeography of the Atlantic Ocean. Mar. Micropaleontol., 1, 119-194.

Roberts, D. G., Schnitker, D., et al., 1984. Init. Repts. DSDP. 81, Washington (U.S. Govt. Printing Office).

Ruddiman, W. F. , Kidd, R. B., Thomas, E., et al., 1983, Site 607. Init. Repts. DSDP, 94, 75-147.

Ruddiman, W. F., Sarnthein, M., et al., 1988. Init. Repts. ODP, 108, Washington (U.S. Govt. Printing Office).

Shackleton, N. J., Backman, J., Zimmerman, H. G., Kent, D.V., Hall, M. A., et al., 1984, Oxygen isotope calibration of the onset of ice-rafting and history of glaciation in the North Atlantic region. Nature, 307, 320-323.

Takayama, T., 1970, The Pliocene-Pleistocene boundary in the Lamont Core V21-98 and at le Castella, southem Italy. J. Mar. Geol., 6, 70-77.

Weaver, P.P. E., and Raymo, M. E., 1989, Late Miocene to Holocene Planktonic Foraminifers from the Equatorial Atlantic. PrOC. $O D P$, Sci. Results, 108, 71-91.

\section{Manuscript received September 1989 \\ Manuscript accepted February 1990.}




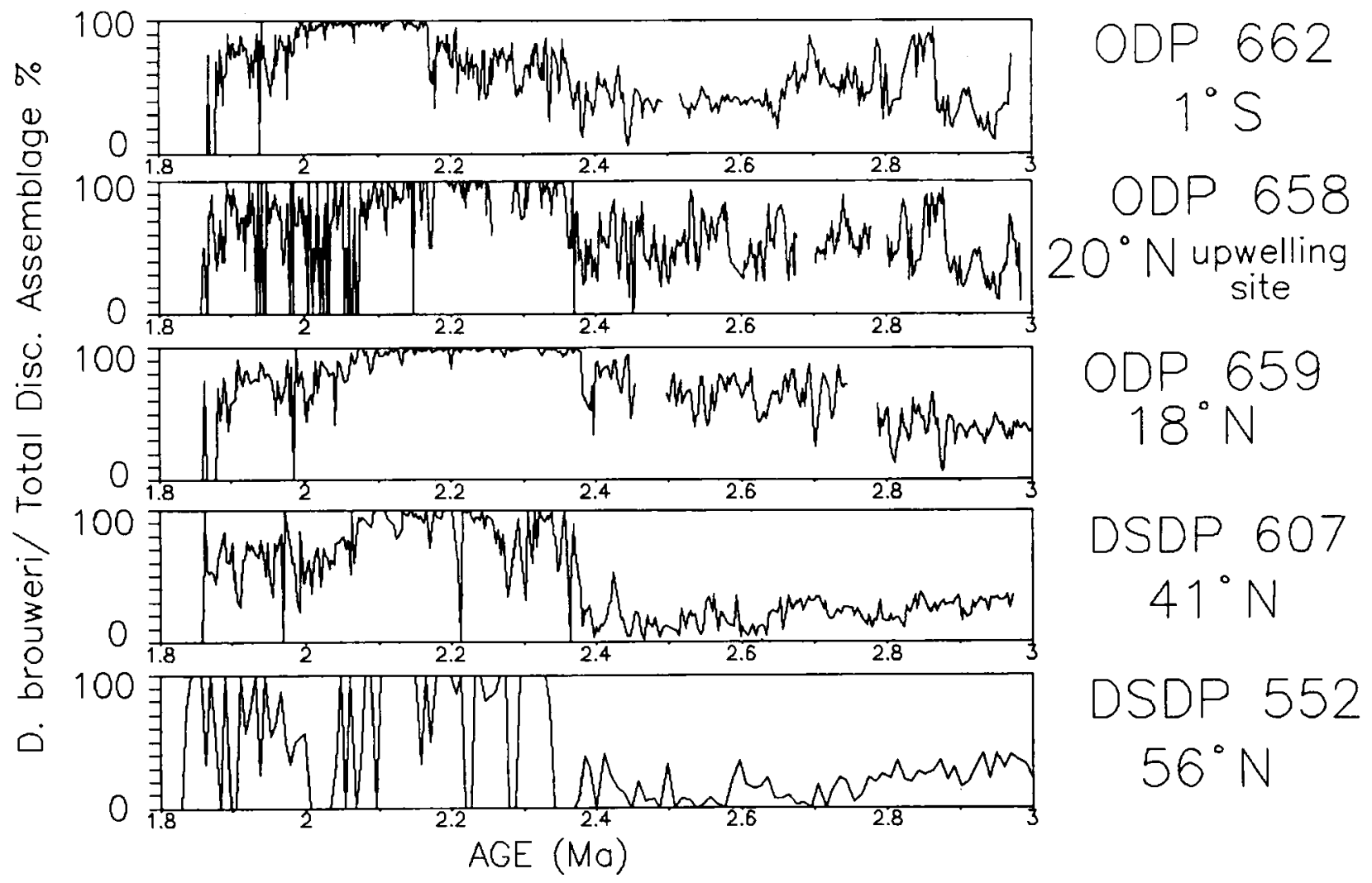

Fig. 2. Percentage abundance plots of D. hrouweri at Sites 552, 607, 659, 658 and 662. Gaps in plots are core breaks.

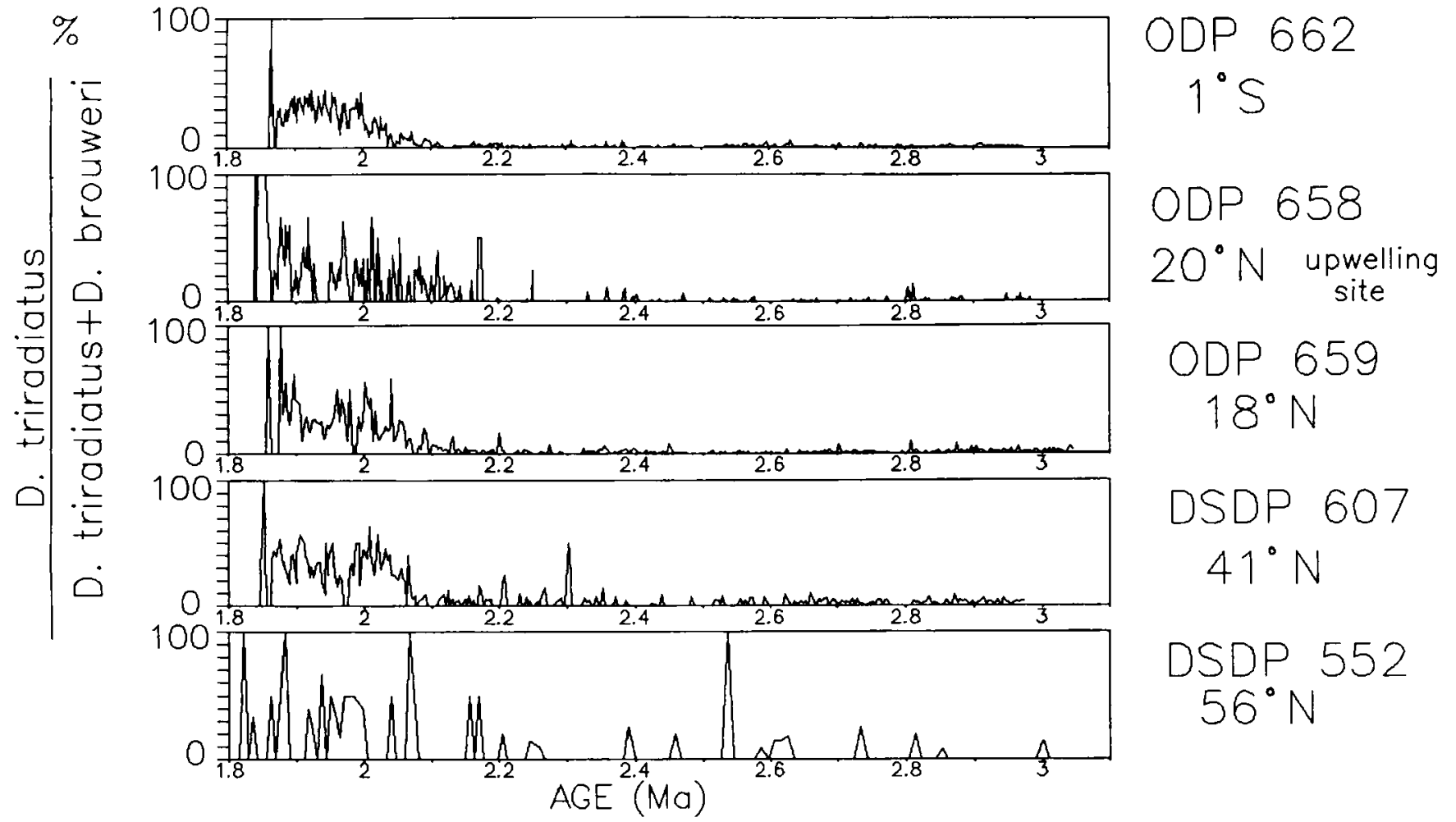

Fig. 3. Percentage plots of D. triradiatus as a percentage of the sum of D. triradiatus and D. brouweri at Sites 552, 607, 659,658 and 662 . 


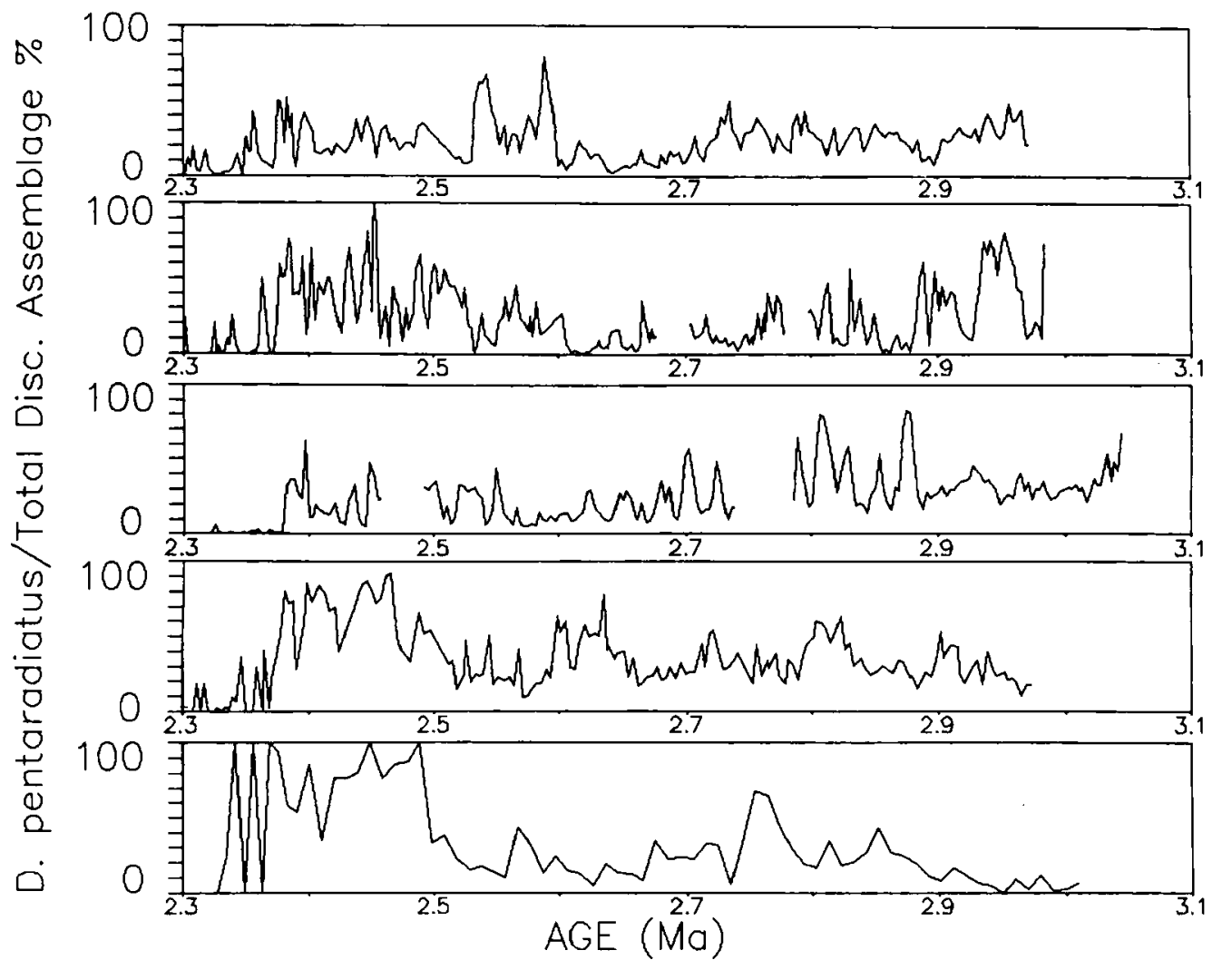

ODP 662

$1^{\circ} \mathrm{S}$

ODP 658 $20^{\circ} \mathrm{N}$ upwelling

ODP 659

$18^{\circ} \mathrm{N}$

DSDP 607

$41^{\circ} \mathrm{N}$

DSDP 552 $56^{\circ} \mathrm{N}$

Fig. 4. Percentage abundance plots of $D$. pentaradiatus at Sites 552, 607, 659, 658 and 662 .

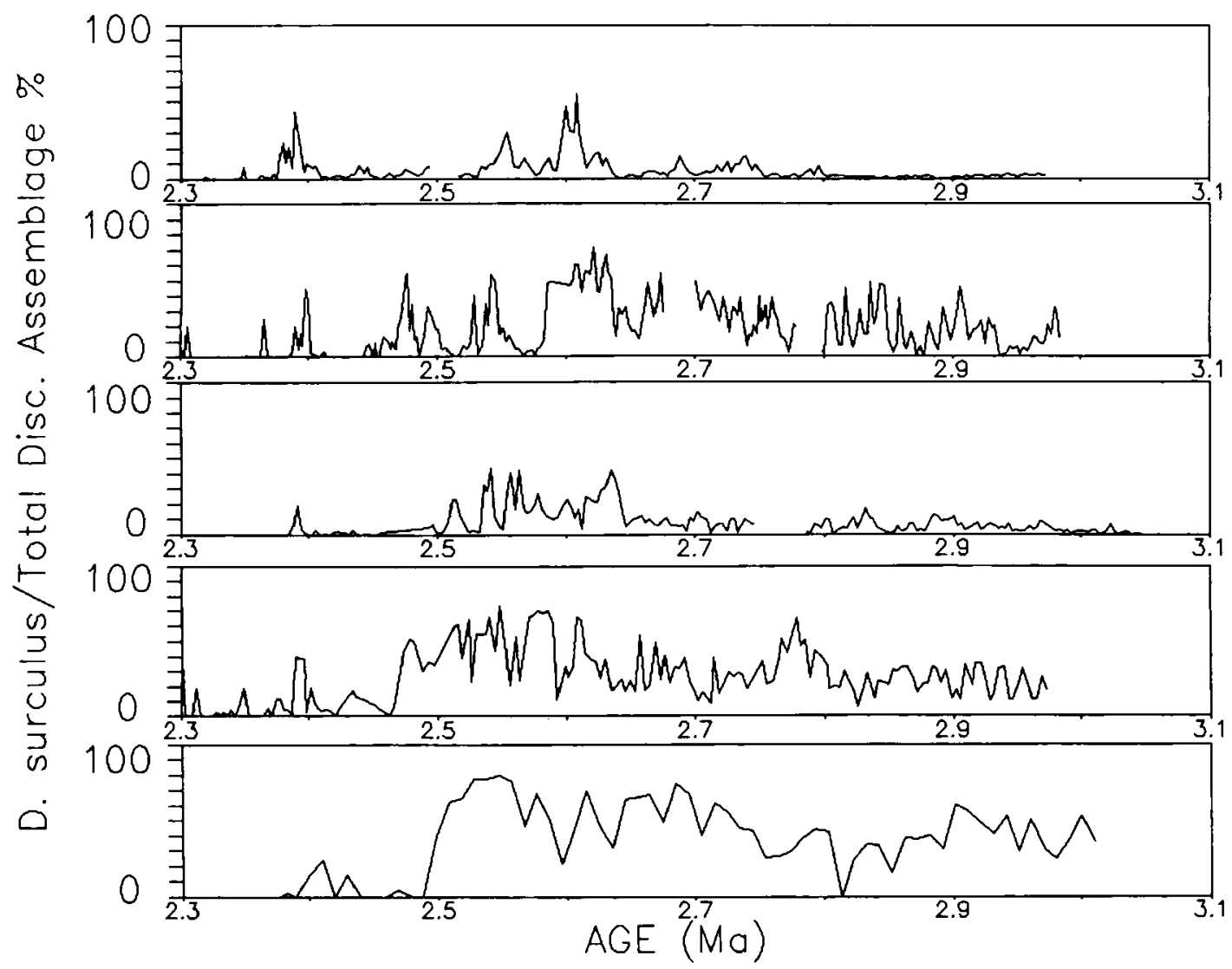

ODP 662 $1^{\circ} \mathrm{S}$

ODP 658 $20^{\circ} \mathrm{N}$ upwelling site

ODP 659 $18^{\circ} \mathrm{N}$

DSDP 607 $41^{\circ} \mathrm{N}$

DSDP 552 $56^{\circ} \mathrm{N}$

Fig. 5. Percentage abundance plots of D. surculus at Sites 552, 607, 659,658 and 662. 


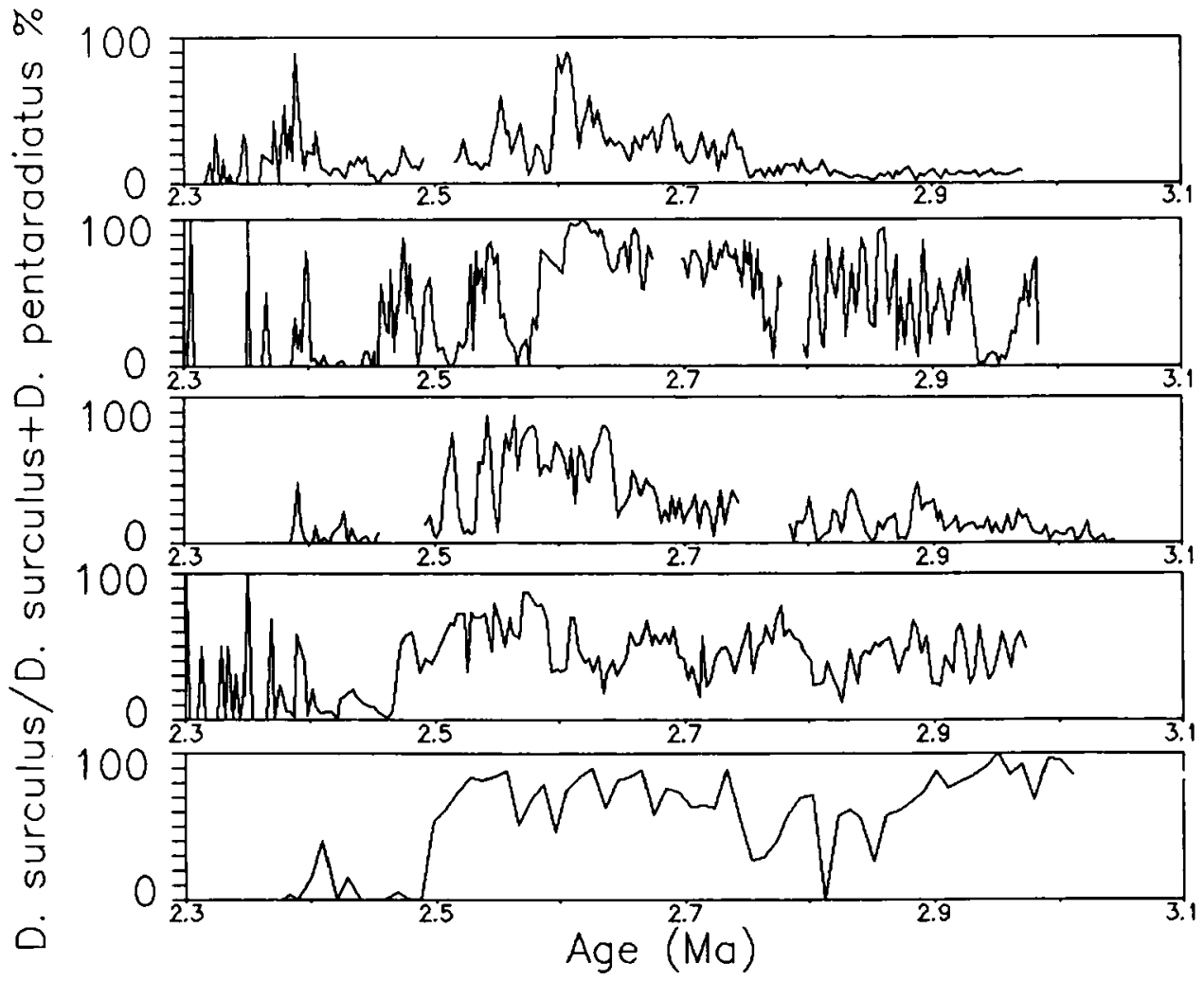

$$
\begin{aligned}
& \text { ODP. } 662 \\
& 1^{\circ} \mathrm{S} \\
& \text { ODP } 658 \\
& 20^{\circ} \mathrm{N} \text { upwelling } \\
& \text { site } \\
& \text { ODP } 659 \\
& 18^{\circ} \mathrm{N} \\
& \text { DSDP } 607 \\
& 41^{\circ} \mathrm{N} \\
& \text { DSDP } 552 \\
& 56^{\circ} \mathrm{N}
\end{aligned}
$$

Fig. 6. Abundance plots of D. surculus as a percentage of the sum of D. surculus and D. pentaradiatus at Sites 552,607,659,658 and 662.

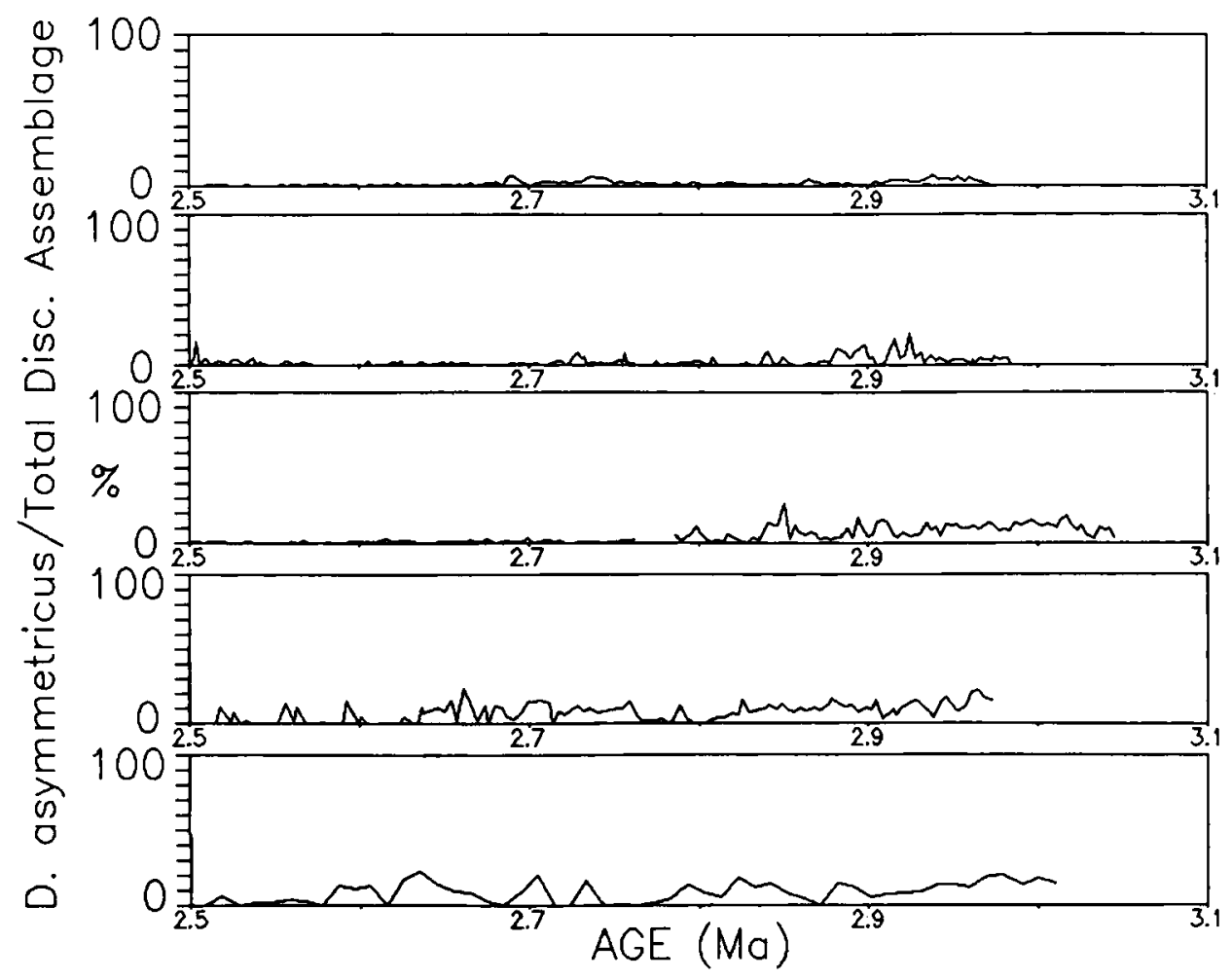

ODP 662 $1^{\circ} \mathrm{S}$

ODP 658 $20^{\circ} \mathrm{N}$ upwelling

ODP 659 $18^{\circ} \mathrm{N}$

DSDP 607 $41^{\circ} \mathrm{N}$

DSDP 552 $56^{\circ} \mathrm{N}$

Fig. 7. Percentage abundance plots of D. asymmetricus at Sites 552, 607,659,658 and 662 . 


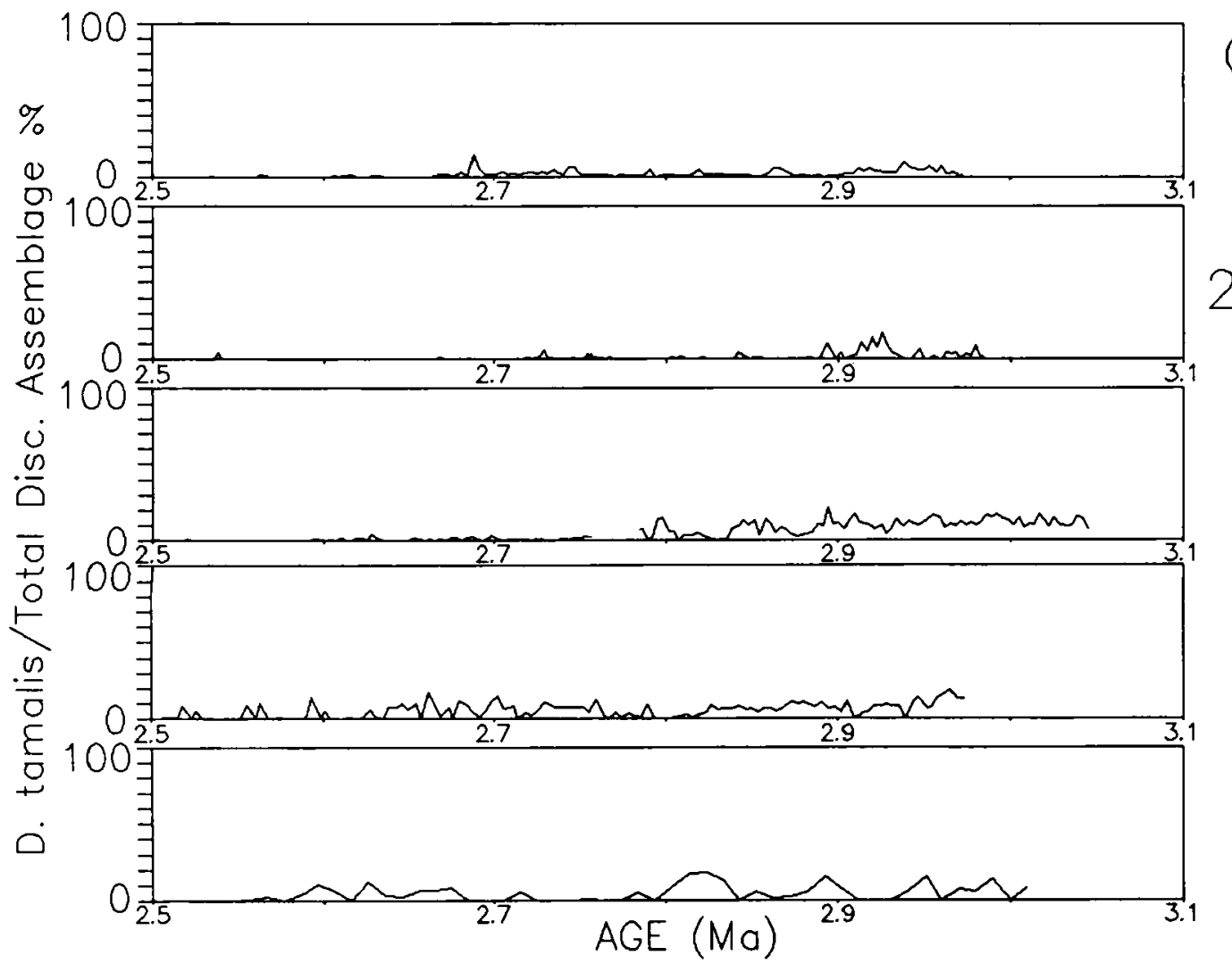

ODP 662

$1^{\circ} S$

ODP 658

$20^{\circ} \mathrm{N}$ upwelling

site

ODP 659

$18^{\circ} \mathrm{N}$

DSDP 607

$41^{\circ} \mathrm{N}$

DSDP 552

$56^{\circ} \mathrm{N}$

Fig. 8. Percentage abundance plots of D.tamalis at Sites 552, 607, 659, 658 and 662 .

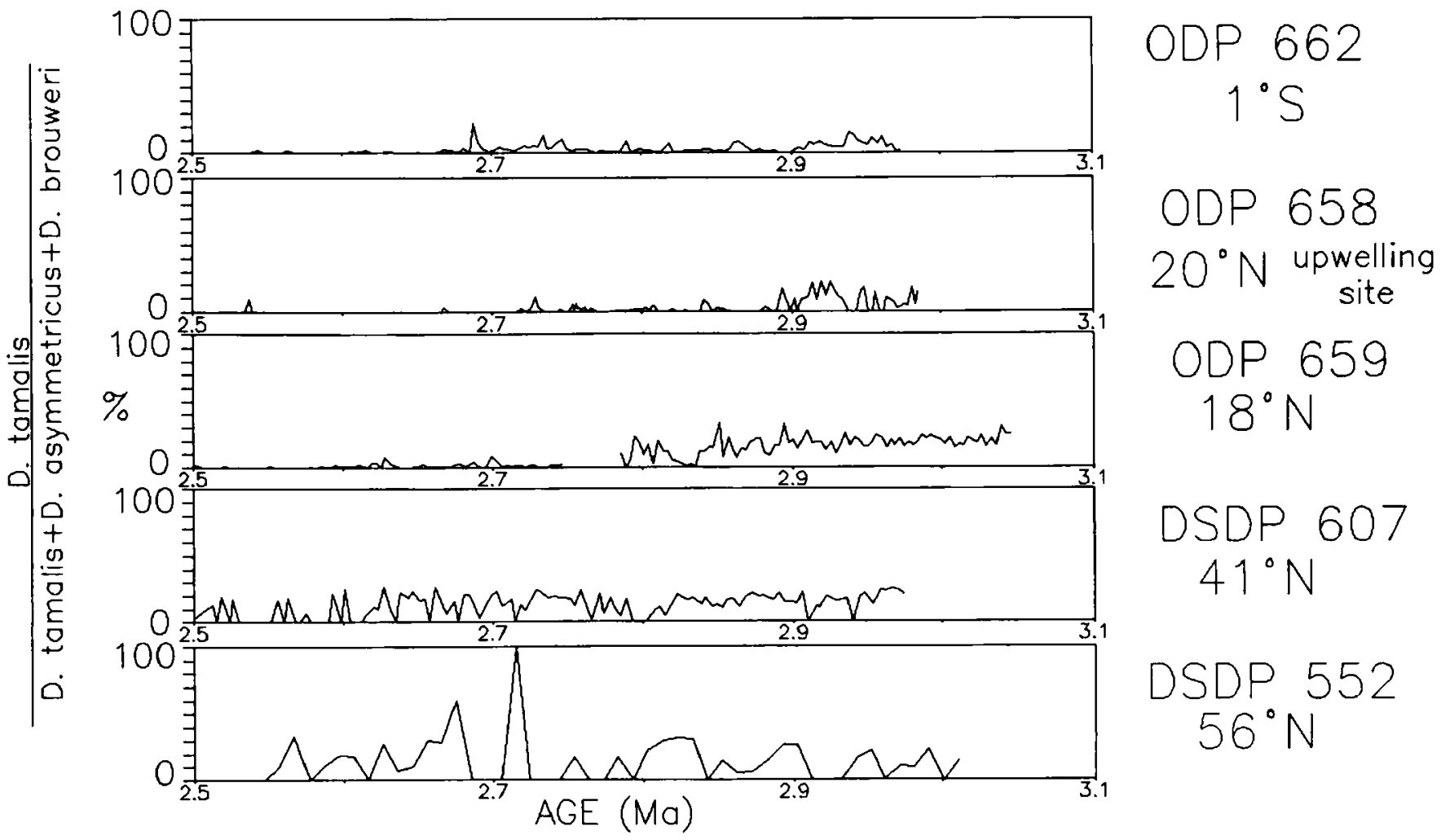

Fig. 9. Abundance plots of D. tamalis as percentage of the sum of D. tamalis. D. assymetricus and D. hrouweri at Sites $552,607,659,658$ and 662 . 


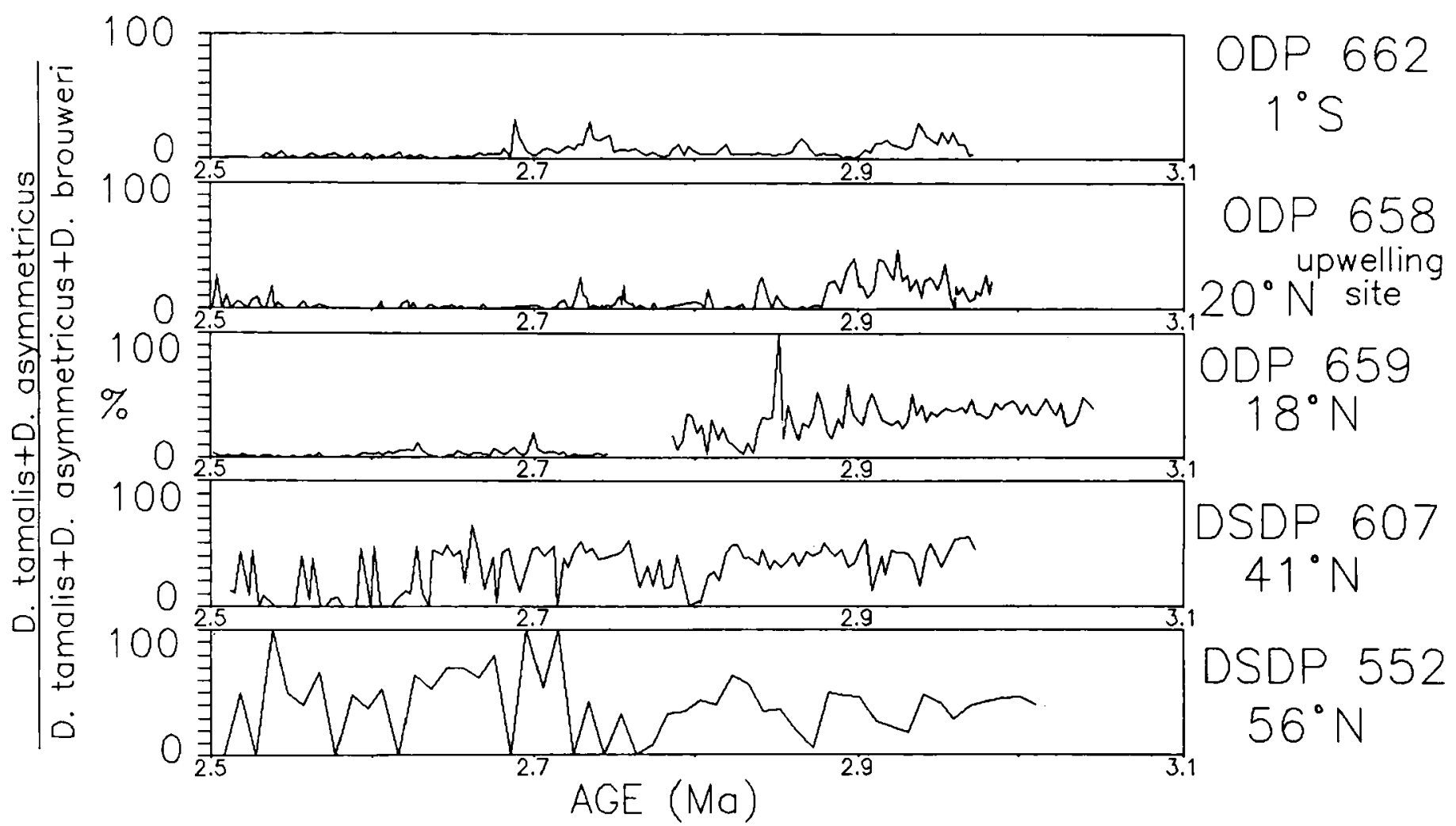

Fig. 10. Abundance plots of D.tamalis and D. assymetricus as a percentage of the sum of these two species and D. brouweri at Sites 552,607,659, 658 and 662 . 